be taken without sensible error as constant throughout small distances near $P$. The same method applies mutatis mutandis to temperature.

The chapter on the diffusion of gases from the point of view of thermodynamics requires more explanation than the author has directly given. $\mathrm{He}$ says ( $p, 125)$ :-

"When two gases at equal temperature and pressure mix by diffusion, the gain of entropy is the same as would occur if each were to expand by escaping into vacuum till it occupied the volume of the mixture."

To this Advocatus Diaboli would say, If instead of two gases you have two quantities of the same gas, oxygen, caeteris paribus, the whole system remains throughout in the same physical state, and, therefore (art. $86[2]$ ), there is no gain of entropy. What difference can it make that one volume of oxygen is replaced by nitrogen?

I think Prof. Bryan would justify his statements thus :- He asserts, art. 124 (a), " as two gases at equal pressure and temperature in general tend to mix by diffusion and not to separate, the process of diffusion is irreversible." And he implies $(b)$ that every irreversible process necessarily jnvolves increase of entropy. If these principles $(a)$ and $(b)$ be granted, 125 is probably justified. But they are both very questionable.

It is not possible within the limits of this notice adequately to discuss either $(a)$ or $(b)$. I would, however, point out that in diffusion, as in all motions of gases, if at any instant the velocities of all the molecules were reversed the system, if isolated, would retrace its course. Does not this fact make a broad distinction between diffusion of gases and irreversible processes usually admitted as such?

\section{S. H. Burbury}

\section{VOLCANOES.}

I Vulcani Astivi della Terra. Mortologia-Dinamismo -Prodotti Distribuzione Geografica-Caure. By G. Mercalli. Pp. viii +42 I ; illu Trged (Milano: Ulrico Hoepli, 1907.) Price IO Ije.

THIS history of the study of volcanoes may be 1 dividg int 5 three periods; the earliest is covered by the froghentry remains of the writings of classical philosopues: 'and the sporadic records of great eruptions of Vesuvius and Etna during the Middle Ages; the second commenced with the eruption of Vesuvius in 1631 , which gave rise to over 200 publications, and from this date on we have a fairly complete record of the activity of Vesuvius and Etna; in the third period, observation became systematised, and vulcanology, as a science, may be said to date from Spallanzani's study of Stromboli in I788. In the nineteenth century the science expanded its boundaries, volcanoes in other parts of the world besides Italy began to be studied, experimental methods were applied to elucidating the mechanism of eruptions and the formation of volcanic rocks, and the microscope to the investigation of their composition and structure.

As a consequence of this expansion of the science it has come to pass that we have had to look, not NO. I 969 , VOL. 757 to Italy, but to other countries, and especially to England, for a general handbook; Prof. Mercalli has rectified this, and the country where the study of volcanoes, and the science of vulcanology, took their birth has produced the best and most complete guide to their pursuit. In the compass of a moderate sized book, we have a remarkably complete, well-balanced review of the subject, which commences with the final result of volcanic activity, in an account of the rocks produced, and works back through the forms of volcanoes, their dynamics, and distribution, to the cause of volcanic activity.

The longest and most generally interesting chapter in the book is doubtless that dealing with the dynamics of volcanoes. Fissure eruptions and the outflow of lava without the formation of a volcanic cone are recognised, and in the classification of volcanic explosions we come across a third type-in addition to the familiar vulcanian and strombolian types-in what are termed plinian eruptions. This name is applied to the violent explosive eruptions, like that of Vesuvius in 79 A.D., of Bandaisan and of Krakatoa, which follow prolonged periods of repose, are of extraordinary violence, are accompanied by comparatively little or no outpouring of lava, while causing the ejection of large volumes of previously solidified material, and are succeeded by another period of repose. The eruptions of Pelee and St. Vincent in rgoz are regarded as differing in degree only, not in kind, from other known eruptions; the celebrated spine of Pelêe, which was thrust up to rooo feet above the crater; was an extreme case of extrusion of solidified lava, and the "black cloud" an extreme case of the avalanches of incandescent ashes which are a not unoommon accompaniment of great eruptions.

In dealing with the cause of volcanic activity, Prof. Mercalli favours the view, first propounded by Seneca, that it is produced by the access of sea water to highlyheated material in the interior of the earth, resulting in the production of high-pressure steam; but here, as elsewhere throughout the book, the theory is not pressed, and alternative explanations are fairly stated. A word, too, may be said for the illustrations, which are numerous and excellent.

\section{OUR BOOK SHELF.}

Shaft Sinking in Difficult Cases. By J. Riemer; translated from the German by W. Brough. Pp. xii + I22; with 18 ill tratighs lnd I9 folding plates. (London: Gharleo Geftin and Co., Ltd., I907.) Price, ros. 6\% net

Mr. RAE on simking, and a translation of his valuable treatise forms an addition to English technical literature that is specially welcome in view of the fact that shaft sinking, the most complicated of all mining problems, is necessarily dealt with in a brief manner in the standard works on coal-mining. The volume is confined to a description of means that have to be resorted to when ordinary methods of sinking cannot be applied on account of excessive influx of water, the means described being shaft sinking by hand, boring shafts, the freezing method of sinking, and the sinking-drur. method.

The particulars given relate exclusively to recent 